\title{
MARCIN PODLEŚ
}

ORCID: 0000-0002-4365-7569

Uniwersytet Wrocławski

\section{OBOWIĄZEK WNIESIENIA WKŁADU PIENIĘŻNEGO W SPÓŁCE Z OGRANICZONĄ ODPOWIEDZIALNOŚCIĄ - WYBRANE ZAGADNIENIA}

\begin{abstract}
Abstrakt: Polskie prawo jednoznacznie stanowi, że wkłady do spółki z o.o. powinny być wnoszone przed złożeniem wniosku o rejestrację spółki do rejestru przedsiębiorców, ale wyłączając od tego obowiązku spółki z o.o. zakładane w systemie teleinformatycznym ze względu na ich z reguły bardzo krótką fazę spółki w organizacji. Polskie prawo przewiduje również dotkliwe konsekwencje dla zarządu w razie złożenia nieprawdziwego oświadczenia w odniesieniu do wkładów wspólników. Zarząd narażony jest w takiej sytuacji na solidarną wraz ze spółką odpowiedzialność wobec wierzycieli spółki za wszystkie zobowiązania spółki przez trzy lata od dnia zarejestrowania spółki. Nie zwalnia przy tym od tej odpowiedzialności następcze dokonanie wniesienia przez wspólników wkładów pieniężnych. Dodatkowo złożenie przez zarząd nieprawdziwego oświadczenia w zakresie wniesienia wkładów zostało zagrożone sankcją karną. Tymczasem w obrocie rozpowszechnione jest zjawisko dokonywania wpłat środków pieniężnych tytułem wkładów na rachunek bankowy spółki dopiero po zarejestrowaniu spółki i założeniu dla zarejestrowanej spółki rachunku bankowego. Z uwagi na brzmienie przepisów regulujących wnoszenie wkładów nie można utożsamiać samej możliwości wpływania przez zarząd na wspólników w celu wykorzystania na potrzeby spółki umówionych wkładów pieniężnych z wniesieniem tych wkładów do spółki, dopóki to wniesienie faktycznie nie nastąpi. W takiej sytuacji w ujęciu systemowym należałoby de lege ferenda postulować możliwość rozszerzenia także na spółki z o.o. zakładane w sposób tradycyjny rozwiązania w zakresie wnoszenia wkładów analogicznego do tego, jakie jest przewidziane dla spółek S24. Konsekwentnie egzekwowany wymóg wniesienia wkładów pieniężnych do spółki z o.o. w organizacji może bowiem stwarzać przeszkodę poważnie spowalniającą w praktyce czas założenia spółki z o.o., co jest niepożądane.
\end{abstract}

Słowa kluczowe: spółka z ograniczoną odpowiedzialnością, kapitał zakładowy, wkłady pieniężne do spółki

\section{WPROWADZENIE}

Spółka z ograniczoną odpowiedzialnością jest obecnie najczęściej występującą w Polsce w obrocie gospodarczym formą spółki ${ }^{1}$. Jednocześnie jest to forma prawna

1 Według danych statystycznych na koniec 2018 roku w Polsce zarejestrowanych było ponad 400 tysięcy spółek z o.o. — por. Mały Rocznik Statystyczny GUS 2019. 
oparta wciąż na konstrukcji kapitału zakładowego, w której — z wyjątkiem spółek rejestrowanych w systemie teleinformatycznym (S24) — wymagane jest wniesienie przez wspólników wkładów na jego pokrycie najpóźniej do momentu złożenia wniosku do sądu rejestrowego o wpis spółki do rejestru przedsiębiorców. W niniejszym opracowaniu przeanalizowane zostaną zagadnienia związane z obowiązkiem wniesienia przez wspólników wkładów pieniężnych na etapie zakładania spółki. Zagadnienie to wydaje się o tyle istotne, że według własnej obserwacji praktyki w obrocie rozpowszechnione jest aktualnie zjawisko dokonywania wpłat środków pieniężnych tytułem wkładów na rachunek bankowy spółki dopiero po zarejestrowaniu spółki. Przybliżone zostaną przepisy określające obowiązek w zakresie wnoszenia wkładów w spółce z o.o. i dotyczące potwierdzenia tej okoliczności przez zarząd. Następnie zarysowane zostaną przepisy odnoszące się do sytuacji nieprawdziwości oświadczeń zapewniających o wniesieniu wkładów do spółki z o.o. W końcu przeanalizowana zostanie praktyka spóźnionego wnoszenia wkładów pieniężnych z punktu widzenia obowiązujących przepisów i przewidzianych w nich sankcji.

\section{OBOWIĄZEK WNIESIENIA WKŁADÓW W SPÓŁCE Z O.O. A WKŁADY PIENIĘŻNE}

Na tle przepisów kodeksu spółek handlowych zobowiązanie wszystkich wspólników spółki z o.o. do wniesienia wkładów jest elementem przedmiotowo istotnym umowy spółki ${ }^{2}$ - podstawowym obowiązkiem wspólnika. W literaturze przedmiotu wskazuje się, że wkłady pieniężne mogą mieć postać gotówki lub pieniądza bankowego ${ }^{3}$. W ramach podziału logicznego (zupełnego) wkłady pieniężne są przeciwstawiane wkładom niepieniężnym (aportom). Wkład pieniężny ma polegać na przekazaniu przez wspólnika do majątku spółki wartości wyrażonej w pieniądzach, zarówno w walucie polskiej, jak i obcej ${ }^{4}$.

Przepisy kodeksu spółek handlowych nie definiują pojęcia wniesienia wkładu. W literaturze sposoby wnoszenia wkładów pieniężnych rozróżnia się ze względu na postać wkładu pieniężnego, przy gotówce wymagając jej wręczenia lub wpłaty na rachunek spółki, a przy pieniądzu bankowym — polecenia przelewu na rachunek spółki czy też przekazu lub czeku bankowego (rozrachunkowego) ${ }^{5}$.

2 Por. art. 3 w zw. z art. 163 pkt 2 k.s.h.

3 Por. przykładowo A. Szumański, Wkłady niepieniężne do spółek kapitałowych, Warszawa 1997, s. 22 n.

4 Por. K. Kopaczyńska-Pieczniak, [w:] Kodeks Spótek Handlowych, t. 2. Komentarz do art. 151-300, red. A. Kidyba, Warszawa 2018, s. 103.

5 Por. A. Szumański, op. cit., s. 22. W odniesieniu do przekazu warto odnotować również stanowisko wyrażone w literaturze, że nie jest on w ścisłym rozumieniu sposobem wniesienia wkładu, lecz może być wykorzystany przez wspólnika wnoszącego zobowiązanie do wykonania jego zobowiązania - por. A. Nowacki, Spótka z ograniczona odpowiedzialnością. Komentarz. Art. 151-226, Warszawa 2018, s. 208-209. Z kolei pomimo pełnienia przezeń również w określonych przypadkach 
Oprócz wniesienia wkładu wymagane jest, aby przedmiot wkładu pozostawał do „wyłącznej dyspozycji zarządu spółki” (art. 158 § 3 k.s.h.). W doktrynie pod pojęciem tym rozumie się zarówno prawną, jak i faktyczną możliwość dysponowania przedmiotem wkładu ${ }^{6}$. Mogłoby się wydawać, że wymóg ten odnosi się przede wszystkim do wkładów niepieniężnych, ponieważ w wypadku wkładów pieniężnych - po ich wniesieniu do spółki — spółka może nimi rozporządzać, przykładowo udzielając pożyczek. Już jednak przy wpłatach wkładów na rachunki nienależące do spółki, lecz przez spółkę wskazane, może on także mieć istotne znaczenie dla wkładów pieniężnych. Wniesienie wkładu pieniężnego następuje zatem odpowiednio przez przekazanie spółce (zarządowi) w posiadanie gotówki lub wpłatę na konto $\mathrm{z}$ momentem dokonania uznania na tym koncie ${ }^{7}$. Podkreśla się charakter oddawczy długu pieniężnego wynikający z obowiązku wniesienia wkładu określonego umową spółki, co implikuje obowiązek jego spełnienia do rąk wierzyciela lub na wskazany przez niego rachunek ${ }^{8}$. W literaturze dopuszcza się również wniesienie wkładu na rachunek zastrzeżony (rachunek escrow) ${ }^{9}$, lecz jego ustanowienie wymaga także podpisania umowy z bankiem z udziałem spółki w organizacji, a dodatkowo wykorzystanie tego instrumentu może budzić wątpliwości pod kątem pozostawania przedmiotu wkładu do ,wyłącznej dyspozycji zarządu spółki” (art. $158 \S 3$ k.s.h.) ${ }^{10}$. To samo dotyczy wpłat na rachunki bankowe należące do innych osób, a wskazane na potrzeby wniesienia wkładu pieniężnego wspólnikom przez spółkę, jak przykładowo rachunek depozytowy notariusza czy też rachunek któregoś ze wspólników. Oczywiście umowa między spółką w organizacji a podmiotem, na który dany rachunek jest prowadzony, mogłaby dać spółce w organizacji narzędzie do dysponowania tymi środkami, chociaż można mieć wątpliwości, na ile to dysponowanie spełniałoby cechę wyłączności. Należy przy tym zauważyć, że sam wymóg pozostawania przedmiotu wkładu do wyłącznej dyspozycji spółki nie jest objęty oświadczeniem składanym przez zarząd na etapie rejestracji spółki. Nie implikuje on zatem bezpośrednio odpowiedzialności zewnętrznej zarządu. Za sposób udowodnienia wykonania zobowiązania do wniesienia wkładu pieniężnego uznaje się przedstawienie pokwitowania wierzyciela względnie dowodu dokonania przelewu bankowego, natomiast dowodu spełnienia

funkcji obiegowej zakwestionowano możliwość traktowania wręczenia weksla jako wkładu pieniężnego - por. J.A. Strzępka, E. Zielińska, [w:] J.A. Strzępka et al., Kodeks spółek handlowych. Komentarz. Orzecznictwo, Warszawa 2003, s. 430.

${ }^{6}$ Tak A. Herbet, [w:] System Prawa Prywatnego, t. 17A. Prawo spótek kapitałowych, red. S. Sołtysiński, Warszawa 2015, s. 237.

7 Tak Z. Jara, [w:] Kodeks spótek handlowych. Komentarz, red. Z. Jara, Warszawa 2017, s. 585.

8 Wniosek z art. 2 k.s.h. w zw. z art. $454 \S 1$ zd. 2 k.c.; por. S. Sołtysiński, [w:] System Prawa Prywatnego, t. 17 B. Prawo spółek kapitałowych, red. S. Sołtysiński, Warszawa 2016, s. 66.

9 Por. A. Nowacki, op. cit., s. 211.

10 Trafnie zwraca na to uwagę przykładowo Z. Jara, op. cit., s. 586 n. 
świadczenia pieniężnego nie może zastąpić oświadczenie wspólników jako dłużników o zapłacie ${ }^{11}$.

\section{MOMENT WNOSZENIA WKŁADÓW W PROCESIE TWORZENIA SPÓŁKI Z O.O. I ICH ZNACZENIE Z PUNKTU WIDZENIA KONSTRUKCJI SPÓŁKI}

Według art. 163 pkt 2 k.s.h. ${ }^{12}$ „do powstania” spółki z o.o. wymaga się wniesienia przez wspólników wkładów na pokrycie całego kapitału zakładowego ${ }^{13}$. W doktrynie przyjmuje się istnienie zasady jednoczesności gromadzenia kapitału zakładowego w przypadku spółki z o.o. obejmującej zasadę całkowitej wpłaty na kapitał zakładowy przed rejestracją spółki ${ }^{14}$. $\mathrm{Z}$ wymogiem tym wiąże się zaś obowiązek załączenia do wniosku o wpis spółki do rejestru przedsiębiorców oświadczenia wszystkich członków zarządu, że wkłady do spółki zostały w całości wniesione (art. $167 \S 1$ pkt 2 k.s.h.) ${ }^{15}$. Spółka z o.o. jako spółka właściwa wyposażona w osobowość prawną po jej zarejestrowaniu w rejestrze przedsiębiorców powinna być wyposażona w majątek pochodzący właśnie z pokrycia kapitału zakładowego. Należy zauważyć, że wyjątkiem jest tutaj jedynie spółka zakładana w systemie teleinformatycznym (S24). Spółki takie mają bowiem bardzo skróconą fazę spółki w organizacji, trwającą jedynie przez czas między podpisaniem umowy spółki w systemie teleinformatycznym sądu a zarejestrowaniem tej spółki w rejestrze przedsiębiorców. W praktyce więc wniesienie wkładu do spółki w organizacji w przypadku spółki zakładanej w systemie teleinformatycznym byłoby mocno utrudnione - podważałoby istotę spółki dwudziestoczterogodzinnej, którą ma być szybkość jej utworzenia. $\mathrm{Z}$ tego też względu na podstawie art. 158 $\S 1^{1}$ k.s.h. w odniesieniu do spółki S24 pokrycie kapitału zakładowego może na-

11 Tak wyrok Sądu Apelacyjnego w Gdańsku - I Wydział Cywilny z dnia 7 grudnia 2017 roku, sygn. akt I ACa 975/17, niepubl.

12 Ustawa z dnia 15 września 2000 roku - Kodeks spółek handlowych (Dz.U. Nr 94, poz. 1037 ze zm.); dalej: k.s.h.

13 Można mieć przy tym pewne zastrzeżenia co do brzmienia tego przepisu, ponieważ spółka z o.o. powstaje (jako spółka w organizacji wyposażona w zdolność prawną) już z chwilą zawarcia umowy spółki, a wniesienie wkładów nie jest do tego niezbędne — por. art. $161 \S 1$ k.s.h.

14 Por. przykładowo K. Kruczalak, Prawo handlowe. Zarys wyktadu, Warszawa 1996, s. 156.

15 Zależność tę podkreślono przykładowo w wyroku Sądu Apelacyjnego w Łodzi z dnia 24 marca 2017 roku, sygn. akt I ACa 1228/16, niepubl. W literaturze zaprezentowano pogląd, że to oświadczenie zarządu nie może być ograniczone do samego stwierdzenia o dokonaniu wniesienia wszystkich wkładów zgodnie z prawem, lecz powinno wskazywać konkretne czynności w odniesieniu do poszczególnych składników majątkowych — tak A. Rachwał, [w:] System Prawa Handlowego, t. 2A. Prawo spółek handlowych, red. A. Szumański, Warszawa 2019, s. 785. Wydaje się, że stanowisko to nie ma uzasadnienia normatywnego, więc nie można w taki rozszerzający sposób interpretować obowiązku złożenia przez zarząd oświadczenia o wniesieniu wkładów. 
stąpić w terminie do siedmiu dni od dnia jej wpisu do rejestru. Natomiast w odniesieniu do wszystkich spółek z o.o. zakładanych w sposób tradycyjny wniesienie wkładów w całości przez wszystkich wspólników ma nastąpić na etapie spółki w organizacji, a okoliczność ta potwierdzana jest obligatoryjnie oświadczeniem podpisywanym przez wszystkich członków zarządu i składanym wraz z wnioskiem o zarejestrowanie spółki do sądu rejestrowego (art. 167 § 1 pkt 2 k.s.h.). Co za tym idzie w orzecznictwie za niedopuszczalne uznano złożenie przez wspólnika — zamiast wniesienia wkładu — oświadczenia o zobowiązaniu do dokonaniu w przyszłości płatności określonej sumy pieniężnej na rzecz spółki ${ }^{16}$.

Obserwacja praktyki wskazuje jednak, że znaczna część spółek z o.o. zakłada rachunki bankowe dopiero po zarejestrowaniu spółki. W praktyce obrotu nie wszystkie banki oferują możliwość założenia rachunku bankowego dla spółki $\mathrm{z}$ o.o. w organizacji. W wypadku spółek w organizacji banki oferujące tego rodzaju produkt wymagają od spółek w organizacji poszerzonego katalogu dokumentów, co również jest swoistym utrudnieniem. W rezultacie wpłata wkładów pieniężnych przez wspólników na kapitał zakładowy dokonywana jest często dopiero po wpisaniu spółki do rejestru przedsiębiorców, co jest potwierdzone treścią odpisu z KRS. Rachunek bankowy jest zaś przy wkładach pieniężnych niezmiernie istotny, ponieważ — szczególnie przy wkładach wyższej wartości — trudno wyobrazić sobie przekazywanie wkładów pieniężnych w formie gotówkowej. Co więcej, w praktyce obrotu niektórzy wspólnicy polskich spółek z o.o. mają miejsca zamieszkania lub siedziby za granicą, co jest dodatkową przeszkodą faktyczną, a w niektórych sytuacjach również prawną, do przekazywania środków pieniężnych bez wykorzystania rachunku bankowego. Data dokonania przelewu na rachunek spółki (wpływu środków na rachunek) wraz z określeniem tytułu przelewu (na przykład jako wpłata tytułem wkładu na kapitał zakładowy) utrwala moment dokonania czynności i w łatwy sposób może wskazywać na niewykonanie dyspozycji kodeksu spółek handlowych co do momentu wniesienia wkładu do spółki. Tymczasem w spółce z ograniczoną odpowiedzialnością jako spółce kapitałowej kapitał zakładowy odgrywa istotną rolę — według założenia powinien w szczególności spełniać tak zwaną funkcję gwarancyjną, służąc jako pewien minimalny „fundusz potencjalnego zaspokojenia się wierzycieli spółki”" ${ }^{17}$. Wskazuje się jednak, że adresatem funkcji gwarancyjnej kapitału zakładowego są wspólnicy

16 Por. uchwałę Sądu Najwyższego z dnia 2 marca 1993 roku, sygn. akt III CZP 123/92, OSNC 1993, nr 10, poz. 167.

17 Por. przykładowo A. Szumański, op. cit., s. 72 n.; A. Nowacki, op. cit., s. 200. W literaturze przedmiotu jednakże już od lat obecne jest kwestionowanie roli kapitału zakładowego w zakresie ochrony wierzycieli spółki i tym samym jego funkcji gwarancyjnej — por. przykładowo A.W. Wiśniewski, Prawo o spótkach. Podręcznik praktyczny, t. 2, Warszawa 1994, s. 100 n. Z kolei na temat koncepcji reform kapitału zakładowego zamiast wielu por. M. Żurek, Reforma regulacji prawnej kapitalu zakładowego spółki z ograniczona odpowiedzialnością. Problematyka ochrony wierzycieli, Warszawa 2018, s. 20 n. 
(a nie wierzyciele spółki), ponieważ wyznacza ona wspólnikom określone zasady postępowania w odniesieniu do środków zgromadzonych na pokrycie kapitału zakładowego, podczas gdy wierzyciele powinni być chronieni przed niedokapitalizowaniem spółki ${ }^{18}$. W orzecznictwie - w związku z funkcją gwarancyjną kapitału zakładowego — sformułowano wymogi jego ścisłego oznaczenia, całkowitej wpłaty (pokrycia) oraz stałości osiąganej przez umieszczenie go w bilansie po stronie pasywów ${ }^{19}$. Ważnym elementem służącym zapewnieniu pełnienia przez kapitał zakładowy funkcji gwarancyjnej jest zatem doprowadzenie do realnego pokrycia tego kapitału wkładami wnoszonymi przez wspólników, a odpowiadającymi co najmniej wartości nominalnej obejmowanych udziałów w kapitale zakładowym $^{20}$.

\section{SKUTKI PRAWNE ZŁOŻENIA NIEPRAWDZIWEGO OŚWIADCZENIA O WNIESIENIU WKŁADÓW W ŚWIETLE PRZEPISÓW KODEKSU SPÓŁEK HANDLOWYCH}

Przepisy kodeksu spółek handlowych przewidują dotkliwe skutki w razie złożenia przez zarząd niezgodnego z prawdą oświadczenia o wniesieniu wkładów. Otóż w pierwszym rzędzie przewidziana została odpowiedzialność majątkowa zewnętrzna członków zarządu wobec wierzycieli spółki. Zgodnie bowiem z art. 291 k.s.h. w razie podania umyślnie lub przez niedbalstwo (a zatem w sposób zawiniony) fałszywych danych w oświadczeniu o wniesieniu wkładów do spółki członkowie zarządu odpowiadają solidarnie wraz ze spółką wobec wierzycieli za wszystkie zobowiązania spółki przez trzy lata od dnia jej zarejestrowania. Odpowiedzialność nie ma przy tym charakteru odszkodowawczego, co za tym idzie — nie jest ograniczona do wysokości szkody wyrządzonej osobie trzeciej złożeniem nieprawdziwego oświadczenia ani do wysokości niewniesionych wbrew treści oświadczenia wkładów. W doktrynie wskazuje się na gwarancyjny charakter tej odpowiedzialności czy też „represyjny lub karno-porządkowy”21. Co więcej, odpowiedzialności tej nie uchyla okoliczność, że już po złożeniu oświadczenia

18 Tak A. Szumański, op. cit., s. 22 n. Autor, broniąc funkcji gwarancyjnej kapitału zakładowego, stawia równocześnie tezę, że dzięki swojej stałości jednoznaczność kwotowa pełni funkcje gwarancyjne również dla wierzycieli spółki jako gwarancja o charakterze ,podstawowym i minimalnym".

19 Por. wyrok Sądu Najwyższego z dnia 8 listopada 1993 roku, sygn. akt II KRN 220/93, niepubl.

20 Przykładowo w wyroku Sądu Najwyższego z dnia 19 marca 1997 roku, sygn. akt II CKN 31/97, niepubl., podkreślono, że wniesienie kapitału zakładowego jest fundamentem działalności gospodarczej spółki z ograniczoną odpowiedzialnością i jest niezbędne do jej funkcjonowania oraz istotne dla kontrahentów spółki.

21 Por. J. Zawarska, Wybrane źródła odpowiedzialności cywilnej członków zarządów spótek kapitałowych, „Wiadomości Ubezpieczeniowe” 2009, nr 4, s. 176. 
wkłady zostały wniesione przez wspólników w pełnej wysokości. Nie ma więc możliwości sanacji dokonanego naruszenia. Dodatkowo złożenie przez zarząd nieprawdziwego oświadczenia w zakresie wniesienia wkładów zostało zagrożone sankcją karną. Otóż według przepisów art. 587 § 1 k.s.h. kto przy wykonywaniu obowiązków wymienionych w tytule III i IV ogłasza dane nieprawdziwe albo przedstawia je organom spółki, władzom państwowym lub osobie powołanej do rewizji, podlega grzywnie, karze ograniczenia wolności albo pozbawienia wolności do lat 2, a jeśli działa nieumyślnie, podlega grzywnie, karze ograniczenia wolności albo pozbawienia wolności do roku. W orzecznictwie zaś złożenie przez zarząd nieprawdziwego oświadczenia jest kwalifikowane właśnie jako przedstawienie nieprawdziwego oświadczenia ${ }^{22}$.

\section{PRAKTYKA „SPÓŹNIONYCH” WPŁAT \\ NA KAPITAŁ ZAKŁADOWY W ŚWIETLE OBOWIĄZUJĄCYCH WYMOGÓW PRAWNYCH}

Mając na uwadze przedstawiony wywód, można przyjąć, że polskie prawo jednoznacznie reguluje moment wnoszenia wkładu do spółki z o.o. i przewiduje dotkliwe konsekwencje w razie niespełnienia tego obowiązku, a doktryna i orzecznictwo stawiają wysokie wymagania odnośnie do rozumienia pojęcia „wniesienia wkładów". Opisany stan w zderzeniu z zaobserwowaną praktyką obrotu dokonywania wpłat na kapitał zakładowy już po zarejestrowaniu spółki w rejestrze przedsiębiorców skłania do rozważenia, czy w odniesieniu do wkładów pieniężnych za tożsame z punktu widzenia wymogu wniesienia wkładu można byłoby uznać jedynie ich faktyczną dostępność dla zarządu spółki na każde żądanie zgłoszone do wspólników, w sytuacji gdy środki te pozostają jeszcze w majątku wspólników. Przykładowo to wspólnicy mogliby — na polecenie zarządu — zanim spółka podejmie właściwą aktywność gospodarczą, pokrywać w imieniu spółki określone koszty powstałe w fazie jej tworzenia (jak koszty notarialne, opłaty sądowe czy też koszty najmu lokalu dla spółki). W świetle wskazanych przepisów, definiujących wniesienie wkładów pieniężnych oraz przyjęte ich rozumienie, należałoby udzielić odpowiedzi negatywnej. Celem obowiązującej regulacji jest bowiem zapewnienie realnego charakteru kapitału zakładowego, aby nie był on jedynie pustym zapisem księgowym po stronie pasywów, lecz aby miał swój odpowiednik po stronie aktywów w postaci praw majątkowych o co najmniej tej samej wielkości wartości majątkowej23. Tak długo zaś, jak środki pieniężne pozostaną u wspólników, nie można ich traktować jako składników majątku spółki czy też jako środków, który-

22 Por. wydany jeszcze na gruncie kodeksu handlowego wyrok Sądu Najwyższego z dnia 8 listopada 1993 roku.

${ }^{23}$ Por. A. Szumański, op. cit., s. 67. 
mi spółka w sposób faktyczny i prawny może wyłącznie dysponować. Formalnie nie zmienia oceny sytuacja, w której członkowie zarządu są jednocześnie wspólnikami, ponieważ mamy do czynienia z odrębnymi masami majątkowymi — spółki oraz wspólników. Tym samym składane przez zarząd oświadczenia o wniesieniu wkładów w opisanej sytuacji obarczone byłyby walorem nieprawdziwości. Sama faktyczna lub prawna możliwość zarządu spółki do sięgnięcia po pieniądze należne $\mathrm{z}$ tytułu umówionego wkładu pieniężnego nie spełnia zatem wymogów prawnych i naraża członków zarządu na ryzyko odpowiedzialności z art. 291 oraz art. $587 \S 1$ k.s.h., które jednak w praktyce rzadko się aktualizuje.

Próbując spojrzeć systemowo na istniejący stan, możemy z jednej strony zauważyć, że wymóg wniesienia wkładów pieniężnych do spółki z o.o. może stwarzać przeszkodę, poważnie spowalniającą w praktyce czas założenia spółki z o.o., co jest niepożądane. $\mathrm{W}$ prawidłowym toku czynności treść obowiązujących przepisów wymusza bowiem z reguły na wspólnikach chcących działać prawidłowo założenie rachunku bankowego dla spółki z o.o. w organizacji i dokonanie wpłat na kapitał zakładowy, zanim zostanie złożony wniosek o wpisanie spółki do rejestru przedsiębiorców. Można bowiem zaobserwować wynikający z różnych czynników odwrót od posługiwania się gotówką, co umożliwiłoby uniknięcie zakładania rachunku bankowego na tak wczesnym etapie istnienia spółki. Wymóg wniesienia wkładów w całości do spółki z o.o. w organizacji nie jest przy tym bezwzględnie stosowany, gdyż - jak wskazano — nie dotyczy on spółek zakładanych w systemie teleinformatycznym (S24). Jednocześnie wniesienie wkładów ma istotne znaczenie z punktu widzenia bezpieczeństwa obrotu i funkcji kapitału zakładowego, czyli konstrukcji, na której opiera się spółka z o.o.. Należy też mieć na uwadze, że wymóg składania przez zarząd oświadczenia o wniesieniu wkładów może być uznany za przejaw do pewnego stopnia liberalnego podejścia ustawodawcy, ponieważ tego rodzaju zapewnienie traktuje on w przypadku spółki z o.o. jako wystarczające do uzyskania przez spółkę z o.o. osobowości prawnej. W naturalny zatem sposób złożenie nieprawdziwego oświadczenia $\mathrm{w}$ tym zakresie powinno być zagrożone sankcjami, aby obowiązek wniesienia wkładów nie miał charakteru wyłącznie fasadowego.

Analizując następstwa „spóźnionego" wniesienia przez wspólników spółki z o.o. wkładów z punktu widzenia ochrony osób trzecich, w szczególności wierzycieli spółki, należy także zauważyć, że ich ochronie służy również daleko idąca dyspozycja art. 13 k.s.h., zgodnie z którą za zobowiązania spółki kapitałowej w organizacji i tak odpowiadają solidarnie (obok spółki) osoby, które działały w jej imieniu (a zatem z reguły zarząd), jak również wspólnicy, przy czym ci ostatni z ograniczeniem do wartości niewniesionego wkładu na pokrycie objętych udziałów ${ }^{24}$. Spółka ma też w stosunku do wspólników wierzytelność o wniesienie

${ }^{24}$ Por. szerzej M. Podleś, Implementacja dyrektywy 2009/101/WE w prawie polskim z perspektywy ochrony wierzycieli, „Przegląd Radcowski” 2014, nr 4, s. 65 n. 
wkładów, a wierzytelność ta może być również przedmiotem zajęcia na rzecz wierzycieli spółki jako elementu majątku spółki.

Mając na uwadze szerszy obraz sytuacji, należy uznać za nadmierne sankcje grożące zarządowi w razie złożenia nieprawdziwego oświadczenia o wniesieniu wkładu, w sytuacji gdy wkłady te zostaną przez wspólników wniesione po zarejestrowaniu spółki i po założeniu jej rachunku bankowego, szczególnie jeśli nastąpi to jeszcze przed rozpoczęciem przez spółkę prowadzenia działalności gospodarczej. Dlatego de lege ferenda należałoby rozważać możliwość rozszerzenia także na spółki z o.o. zakładane w sposób tradycyjny rozwiązania analogicznego do tego, jakie przewidziano dla spółek S24, czyli umożliwienia wspólnikom dokonywania wpłat na kapitał zakładowy w określonym czasie po zarejestrowaniu spółki i tym samym przesunięcia w czasie obowiązku zarządu do składania oświadczenia o dokonanym wniesieniu wkładów do spółki. Natomiast z samego obowiązku składania przez zarząd takiego oświadczenia nie należałoby rezygnować i powinno się odnosić do skutków jego niezłożenia obowiązujące obecnie sankcje. Tego rodzaju zmiana nie powinna negatywnie odbić się na bezpieczeństwie obrotu ani negatywnie wpłynąć na sytuację wierzycieli spółki. Jak wykazuje bowiem obserwacja praktyki, oświadczenie zarządu o wniesieniu wkładów i tak nie jest weryfikowane przez sąd rejestrowy, nie stanowi ono zatem instrumentu realnie uniemożliwiającego zarejestrowanie spółki i uzyskanie przez nią osobowości prawnej. Co więcej, tego rodzaju wyłom stworzony został już przez ustawodawcę dla znacznej grupy spółek z o.o. zakładanych w systemie S24.

\section{OBLIGATION TO MAKE A PECUNIARY CONTRIBUTION TO A LIMITED LIABILITY COMPANY — SELECTED ISSUES}

\section{Summary}

Polish law unequivocally states that contributions to a limited liability company should be made before the application for registration of the company is submitted to the register of entrepreneurs, but excluding from this obligation a limited liability company established in the ICT system due to their usually very short phase of the company's organisation. Polish law also provides for severe consequences for the management board in the event of a false declaration with regard to shareholders' contributions. In such a situation, the management board is exposed to joint and several liability with the company to the company's creditors for all the company's liabilities for three years from the date of the company's registration. This liability is not relieved by the subsequent contribution by the shareholders. In addition, the submission by the management board of an untrue statement concerning the contribution was threatened with a criminal sanction. Meanwhile, the phenomenon of making pecuniary contributions to the company's bank account only after the registration of the company and establishment of a bank account for the registered company is widespread in trade. Due to the wording of the provisions governing contributions, the mere possibility for the management board to influence shareholders in order to use the agreed cash contributions for the needs of the company cannot be equated with making such contributions to the company until the contribution is actually made. In such a situation, it would be appropriate, on a systemic basis, to postulate 
the possibility of extending also to limited liability companies established in a traditional way the arrangements for making contributions similar to those provided for companies, established in the ICT system. The consistently enforced requirement to make pecuniary contributions to a limited liability company in the organisation may create an obstacle, seriously slowing down in practice the period of establishing a limited liability company, which is an undesirable factor.

Keywords: limited liability company, initial share capital, pecuniary contribution to a company

\section{BIBLIOGRAFIA}

Herbet A., [w:] System Prawa Prywatnego, t. 17A. Prawo spółek kapitałowych, red. S. Sołtysiński, Warszawa 2015.

Jara Z., [w:] Kodeks spótek handlowych. Komentarz, red. Z. Jara, Warszawa 2017.

Kodeks spótek handlowych. Komentarz, red. Z. Jara, Warszawa 2017.

Kopaczyńska-Pieczniak K., [w:] Kodeks Spótek Handlowych, t. 2. Komentarz do art. 151-300, red. A. Kidyba, Warszawa 2018.

Kruczalak K., Prawo handlowe. Zarys wykladu, Warszawa 1996.

Nowacki A., Spótka z ograniczona odpowiedzialnościa. Komentarz. Art. 151-226, Warszawa 2018.

Podleś M., Implementacja dyrektywy 2009/101/WE w prawie polskim z perspektywy ochrony wierzycieli, „Przegląd Radcowski” 2014, nr 4.

Rachwał A., [w:] System Prawa Handlowego, t. 2A. Prawo spótek handlowych, red. A. Szumański, Warszawa 2019.

Strzępka J.A., Zielińska E., [w:] J.A. Strzępka, P. Pinior, W. Popiołek, H. Urbańczyk, E. Zielińska, Kodeks spółek handlowych. Komentarz. Orzecznictwo, Warszawa 2003.

System Prawa Prywatnego, t. 17A. Prawo spółek kapitałowych, red. S. Sołtysiński, Warszawa 2015. System Prawa Prywatnego, t. 17 B. Prawo spółek kapitałowych, red. S. Sołtysiński, Warszawa 2016. Szumański A., Wkłady niepieniężne do spótek kapitałowych, Warszawa 1997.

Wiśniewski A.W., Prawo o spótkach. Podręcznik praktyczny, t. 2, Warszawa 1994.

Zawarska J., Wybrane źródła odpowiedzialności cywilnej członków zarząów spółek kapitałowych, „Wiadomości Ubezpieczeniowe” 2009, nr 4.

Żurek M., Reforma regulacji prawnej kapitału zakładowego spótki z ograniczona odpowiedzialnościa. Problematyka ochrony wierzycieli, Warszawa 2018. 